\title{
ETHNOMATHEMATICS AN ALTERNATIVE IN THE DEVELOPMENT OF MULTICULTURAL EDUCATION AT THE PRIMARY SCHOOL
}

\section{Mahpudin, Liyana Sunanto}

Universitas Majalengka, Universitas Muhammadiyah Cirebon mahpudin893@gmail.com, lyana.sunanto@gmail.com

\section{Article History}

accepted 30/09/2018

approved $12 / 10 / 2018$

published 30/10/2018

\section{Keywords}

Multicultural Education,

Ethnamathematics,

Mathematics in Primary

Schools

\begin{abstract}
Classical mathematics learning leads to a false view of students who think that mathematics is a separate field of science from their daily lives. Learning mathematics by using ethnomathematics can bring mathematical concepts closer to students' daily lives so that students can better understand and interpret the learning outcomes they get. In addition, ethnomathamatics can further develop multicultural competencies in students. Students can better know and appreciate cultural diversity.
\end{abstract}

Social, Humanities, and Education Studies (SHEs): Conference Series https://jurnal.uns.ac.id/shes
p-ISSN 2620-9284

e-ISSN 2620-9292 


\section{PENDAHULUAN}

Matematika merupakan bidang ilmu yang harus dikuasai oleh semua orang.Dalam konteks sekolah dasar, matematika menjadi satu mata pelajaran yang penting. Pembelajaran matematika pada tingkat sekolah dasar harus mampu membekali siswa untuk belajar matematika pada jenjang sekolah berikutnya, selain itu pembelajaran matematika di sekolah dasar idealnya harus membuat siswa mampu menerapkan konsep matematika dalam memecahkan masalah dalam kehidupan sehari-hari.

Di dalam kelas-kelas matematika terbaik saat ini, para siswa akan belajar memahami matematika daripada hanya mengikuti langkah-langkah dari prosedurprosedur tertentu. Matematika saat ini diajarkan dengan konteks-konteks yang kaya yang memperjelas kepada para siswa mengenai mengapa mereka harus mengetahui hal tersebut. Pemahaman konseptual dlam matematika, bersamaan dengan keahlian prosedural jauh lebih kuat daripada keahlian prosedural itu sendiri.(Wahyudin, 2013)

Pemaparan di atas memberikan gambaran bahwa yang harus dicapai dalam pembelajaran matematika di skeolah tidak sebatas pada kemampuan dalam menyelesaikan soal matematis sesuai dengan rumus yang sudah ada. Lebih dari itu, pembelajaran matamatika harus sampai pada pembekalan pemahaman terhadap konsep matematika yang selanjutnya pemahaman tersebut dapat digunakan dalam menyelesaikan berbagai bentuk permasalahan matematis, sampai akhirnya muncul sikap menghargai terhadap fungsi dan kegunaan matematik dalam kehidupan seharihari.

Pembelajaran matematik yang biasa disampaikan guru di dalam kelas-kelas di beberapa sekolah di Indonesia khususnya pada jenjang skolah dasar kebanyakan masih berkutat pada menjelaskan konsep, pemberian contoh penyelesaian soal, dan pemberian latihan soal.Bentuk pembelajaran seperti itu cenderung lebih membuat siswa menjadi mengkotak-kotakkan antara permasalahan matematika dengan permasalahan dalam kehidupan sehari-hari, sehingga siswa mampu menyelesaikan soal matematika dengan rumus yang sudah dijelaskan namun tidak mampu mengaitkan konsep matematis yang dipelajari dengan permasalahan dalam kehidupan sehari-hari.

Pembahasan yang tak kalah menarik dalam pembelajaran matematika di sekolah dasar adalah mengenai konteks dalam menyampaian konsep matematika. Penggunaan konteks yang lebih dekat dengan kehidupan siswa terlebih lagi dengan konteks budaya selain akan membawa siswa pada pemahaman konsep matematis juga akan membawa siswa pada pengalaman mengamati kekayaan budaya yang dimilikinya melalui sudut pandang matematika. Hal ini akan menumbuhkan kesadaran pada siswa terhadap keberagaman budaya dan diharapkan mampu menumbuhkan sikap menghargai terhadap kebaragaman tersebut mengingat Indonesia merupakan Negara yang multikultur, selain itu tentunya akan semakin memeprkaya objek dalam mempelajari matematika. Pembahasan mengenai matematika yang bersentuhan langsung dengan pembahasan mengenai budaya yaitu dengan cara mengembangkan pembelajaran berbasis etnomatika. Dengan adanya pengembangan etnomatika, diharapkan mampu membuka pandangan siswa mengenai berbagai objek budaya yang ditinjau dari pembahasan matematis. Selain itu, diharapkan juga munculnya sikap menghargai terhadap budaya yang dimilikinya maupun budaya yang dimiliki orang lain. Sikap menghargai terhadap keberagaman budaya dalam kehidupan sehari-hari siswa dianggap penting untuk ditumbuhkan karena Indonesia merupakan negara yang terdiri dari bermacam-macam agama, suku bangsa, dan bahasa. Dengan adanya sikap saling menghargai akan keberagaman tersebut maka akan semakin memperkokoh persatuan dan kesatuan bangsa. 


\section{HASIL DAN PEMBAHASAN}

\section{Ethnomathematics dalam Pembelajaran Matematika di Sekolah Dasar}

Albanese \& Perales (2015) mengungkapan bahwa"Ethnomathematics is a research programthat focuses on the relationship between mathematics and culture". Etnomatematika merupakan suatu kajian praktik matematik yang berpusat pada budaya tertentu dalam memahami, mengekspresikan, dan menggunakan konsepkonsep serta praktik-praktik kebudayaannya yang digambarkan oleh peneliti sebagai sesuatu yang matematis.

Etnomatematika menekankan praktik matematika berakar budaya. Hal ini didasarkan pada metodologi konstruktivis, yang menawarkan pembelajaran sebagai proses aktif untuk membangun pengetahuan melalui praktik fisik dan sosial yang didukung oleh guru. Memandu praktik ini membutuhkan konten khusus guru dan pengetahuan konten pedagogis, termasuk kemampuan dan motivasi untuk membangun hubungan pribadi dengan siswa, kesadaran akan latar belakang budaya mereka dan mengikuti prinsip-prinsip pendidikan multi-budaya.

Pada dasarnya penggunaan etnomatematika dalam pembelajaran matematika di kelas merupakan aplikasi dari pendekatan Realistics Mathematics Education (RME) atau di Indonesia lebih dikenal dengan Pendekatan Matematika Realistik Indonesia (PMRI) yang mana pendekatan PMRI ini dipandang sebagai pendekatan yang banyak memberikan harapan bagi peningkatan hasil pembelajaran matematika. Guru perlu memahami apa saja yang merupakan pengetahuan dalam matematika dan bagaimana pengetahuan dapat dikaitkan dengan berbagai norma dan nilai dari budaya-budaya yang berbeda. Upaya mengintegrasikan budaya-budaya yang berbeda di ruang kelas memerlukan suat kerangka konseptual untuk membuat keputusan-keputusan pedagogis yang koheren. (Wahyudin, 2018).

Dalam pembelajaran matematika dengan menggunakan etnomatematika, pertama-tama guru mengangkat satu objek pada budaya tertentu sebagai konteks dalam pembelajaran di kelas.Setelah itu guru meminta siswa pada kelas yang multi budaya untuk mengamati objek pada budaya masing-masing yang berkaitan dengan konsep matematika yang sedang dibahas.Siswa mengkomunikasikan hasil pengamatan terhadap objek yang terdapat pada budayanya masing-masing supaya wawasan tersebut bisa tersebar pada teman sekelas yang latar belakang budayanya berbeda-beda.

Penelitian mengenai pembelajaran matematika dengan etnomatematika telah banyak dilakukan, salah satunya adalahRosida (2018), dalam penelitiannya terhadap pembelajaran dengan pendekataan etnomatika berbasis budaya lokal telah memenuhi syarat kriteria efektif terhadap hasil belajar, respon, dan aktivitas siswa.

Sirate (2012) mengemukakan bahwa model kurikulum etnomatematika harus (a) dirancang dalam konteks yang sesuai dan berarti, (b) dalam bentuk konten atau isi budaya khusus yang berbeda dengan konsep matematika umumnya seperti yang diajarkan di kebanyakan sekolah, (c) membangun ide bahwa etnomatematika berada pada tahapan pengembangan pemikiran matematika yang membawa kelas ke dalam konteks budaya, dan (5) merupakan integrasi konsep dan praktik matematika ke dalam budaya siswa yang dapat menjadi bagian dari pendidikan matematika formal yang bersifat konvensional di sekolah.

\section{Multicultural Education}

Multicultural education atau pendidikan multikultural merupakan sebuah tawaran model pendidikan yang mengususng ideologi yang memahami, menghormati, dan menghargai harkat dan martabat manusia dimanapun dia berada dan dari manapun datangnya (secara ekonomi, sosial, budaya, etnis, bahasa, keyakinan atau 
agama, dan negara).Pendidikan multikultural secara inhern merupakan dambaan semua orang, lantaran keniscayaannya konsep "memanusiakan manusia".

Menurut pandangan Azra (Baidhawy, 2005) bahwa secara sederhana multikulturalisme bisa dipahami sebagai pengakuan, bahwa sebuah negara atau masyarakat adalah beragam dan majemuk. Atau dapat pula diartikan sebagai "kepercayaan" kepada normalitas dan penerimaan keragaman.

Berdasarkan penjelasan di atas, multikultural merupakan sebuah pengakuan atau penerimaan atas keberagaman di lingkungan masyarakat. Indonesia sebagai negara yang sangat kaya akan budaya, suku bangsa, agama, dan bahasa. Sudah sepantasnya dalam dunia pendidikan di Indonesia senantiasa memperhatikan pada pengembangan multikulturalisme.Pada dasarnya semboyan bhineka tunggal ika sudah memberikan tuntutan agar memiliki kemampuan multikultural.

Menurut Banks (Danoebroto, 2012) pendidikan multikultural merupakan reformasi pendidikan yang bertujuan untuk: 1) membantu setiap individu mencapai pemahaman diri yang lebih baik melalui perspektif kultural lainnya, 2) melayani siswa dengan keanekaragaman kultur dan etnik, 3)melayani semua siswa dengan keterampilan, bakat dan pengetahuan yang diperlukan agar dapat berkontribusi bagi dirinya sendiri dan bagi masyarakat yang multikultur, dan 4) membantus siswa untuk menguasai keterampilan penting seperti membaca, menulis, dan matematika.

Lebih lanjut lagi Banks (Zamroni, 2010) menyebutkan setidaknya ada lima dimensi dari multikultural education, yaitu: 1). Content integration; 2). The knowledge konstruktion process; 3). Prejudice reduction; 4). An equity pedagogy; dan 5).An empowering school culture and society structure.

Lima dimensi tersebut merupakan cara bagaimana penanaman dan pengembangan kemampuan multikultural dari kelima dimensi tersebut, dalam tulisan ini lebih condong kepada content integration. Dalam hal ini yaitu berkaitan dengan sejauhmana guru menggunakan contoh-contoh, data dan informasi dari berbagai kultur dalam proses pembelajaran mata pejaran yang diampu.

Dalam pembelajaran matematika dengan etnomatematika, multikultural education dikembangkan dengan cara mennggunakan contoh-contoh matematis dengan menggunakan berbagai kultur dengan harapan siswa dapat lebih mengetahui tentang keberagaman dalam kelas mereka, selain mengetahui mengenai keberagaman, dengan penugasan mengamati objek budaya masing-masing, siswa akan lebih bisa menghargai budaya dari teman sekelasnya yang berbeda.

Sebagai contoh, dalam pembelajaran geometri bangun datar, guru menggunakan contoh beberapa bangun datar sebagai atap dari rumah adat daerah tertentu yang merupakan adat dari sebagian siswa. Guru membawa siswa pada pengalaman menyaksikan langsung bentuk rumah adat, lalu mengajak siswa untuk mengamati bagian-bagian dari rumah adat tersebut yang merupakan bentuk bangun datar. Siswa diminta untuk mengidentifikasi ciri-ciri dari masing-masing bentuk bangun datar yang teramati sampai pada pemahaman siswa terhadap sifat-sifat bangun datar yang dimaksud. Setelah satu jenis rumah adat teridentifikasi sifat-sifat bangun datarnya, langkah selanjutnya guru meminta siswa untuk mengamati rumah adat yang lain yang merupakan budaya dari masing-masing siswa lainnya, hal ini dilakukan agar siswa bisa mengetahui lebih banyak keragaman budaya yang ada di dalam kelas, dan pada akhirnya masing-masing siswa diarahkan untuk tumbuh rasa bangga atas kekayaan budaya yang ada di Indonesia.

Dalam konteks pembelajaran di atas, selain membuka wawasan siswa akan keragaman budaya, menumbuhkan rasa saling menghargai satu sama lain, juga akan tumbuh pemahaman siswa terhadap konsep bangun datar. Pemahaman yang akan didapat akan lebih bermakna karena siswa dilibatkan dalam pengalaman belajar yang memberikan siswa keleluasaan dalam mengamati konsep matematika yang diterapkan dalam kehidupan sehari-hari. 


\section{SIMPULAN}

Dalam pembelajaran matematika di sekolah dasar, penggunaan konteks yang lebih dekat dengan kehidupan siswa terlebih lagi dengan konteks budaya selain akan membawa siswa pada pemahaman konsep matematis juga akan membawa siswa pada pengalaman mengamati kekayaan budaya yang dimilikinya melalui sudut pandang matematika. Hal ini akan menumbuhkan kesadaran pada siswa terhadap keberagaman budaya dan diharapkan mampu menumbuhkan sikap menghargai terhadap kebaragaman tersebut.

Ethnomathematics menekankan praktik matematika berakar budaya. Hal ini didasarkan pada metodologi konstruktivis, yang menawarkan pembelajaran sebagai proses aktif untuk membangun pengetahuan melalui praktik fisik dan sosial yang didukung oleh guru.

Multicultural education atau pendidikan multikultural merupakan sebuah tawaran model pendidikan yang mengususng ideologi yang memahami, menghormati, dan menghargai harkat dan martabat manusia dimanapun dia berada dan dari manapun datangnya (secara ekonomi, sosial, budaya, etnis, bahasa, keyakinan atau agama, dan negara).Pendidikan multikultural secara inhern merupakan dambaan semua orang, lantaran keniscayaannya konsep "memanusiakan manusia".

Dalam pembelajaran matematika dengan ethnomathematics, multikultural education dikembangkan dengan cara mennggunakan contoh-contoh matematis dengan menggunakan berbagai kultur dengan harapan siswa dapat lebih mengetahui tentang keberagaman dalam kelas mereka, selain mengetahui mengenai keberagaman, dengan penugasan mengamati objek budaya masing-masing, siswa akan lebih bisa menghargai budaya dari teman sekelasnya yang berbeda.

\section{DAFTAR PUSTAKA}

Danoebroto, S.W. (2012). Model Pembelajaran Matematika Berbasis Pendidikan Multikultural. Jurnal Pembangunan Pendidikan: Fondasi dan Aplikasi. 1(1), 94107

Zamroni. (2010). The Iplementation Of Multicultural Education: A Reader. Yogyakarta: Universitas Negeri Yogyakarta

Wahyudin. (2013a). Matematika Dasar. Pengetahuan bermuatan pedagogis. Bandung: Penerbit Mandiri

Wahyudin. (2018b). Etnomatematika dan Pendidikan Matematika Multikulltural. Prosiding Seminar Nasional Pendidikan Matematika Etnomatnesia.

Sirate, S.F. (2015). Menggagas Integrasi Multikultur Pembelajaran Matematika. Jurnal Pendidikan Dasar Islam. 2(2). 246-263

Albanese, V., \& Perales, F.J. (2015). Enculturatin with ethnomathematical micro projects: from culture to mathematics. Journal of mathematics \& culture, 9(1), 1 11.

Rosida, V., dkk. (2018). Efektivitas Pendekatan Etnomatematika Berbasis Budaya Lokal Dalam Pembelajaran Matematika. Histogram: Jurnal Pendidikan Matematika, 2(2), 97-107 